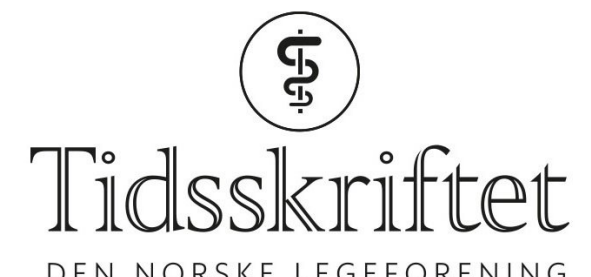

\title{
Det vondes problem
}

INTERVJU

\section{CHARLOTTE LUNDE}

E-post: charlottelunde@me.com

Hva skjer når et menneske mister fortellingen om seg selv? Psykiatrien har vært én av flere veier inn til dette spørsmålet for krimforfatter og tidligere overlege Torkil Damhaug.

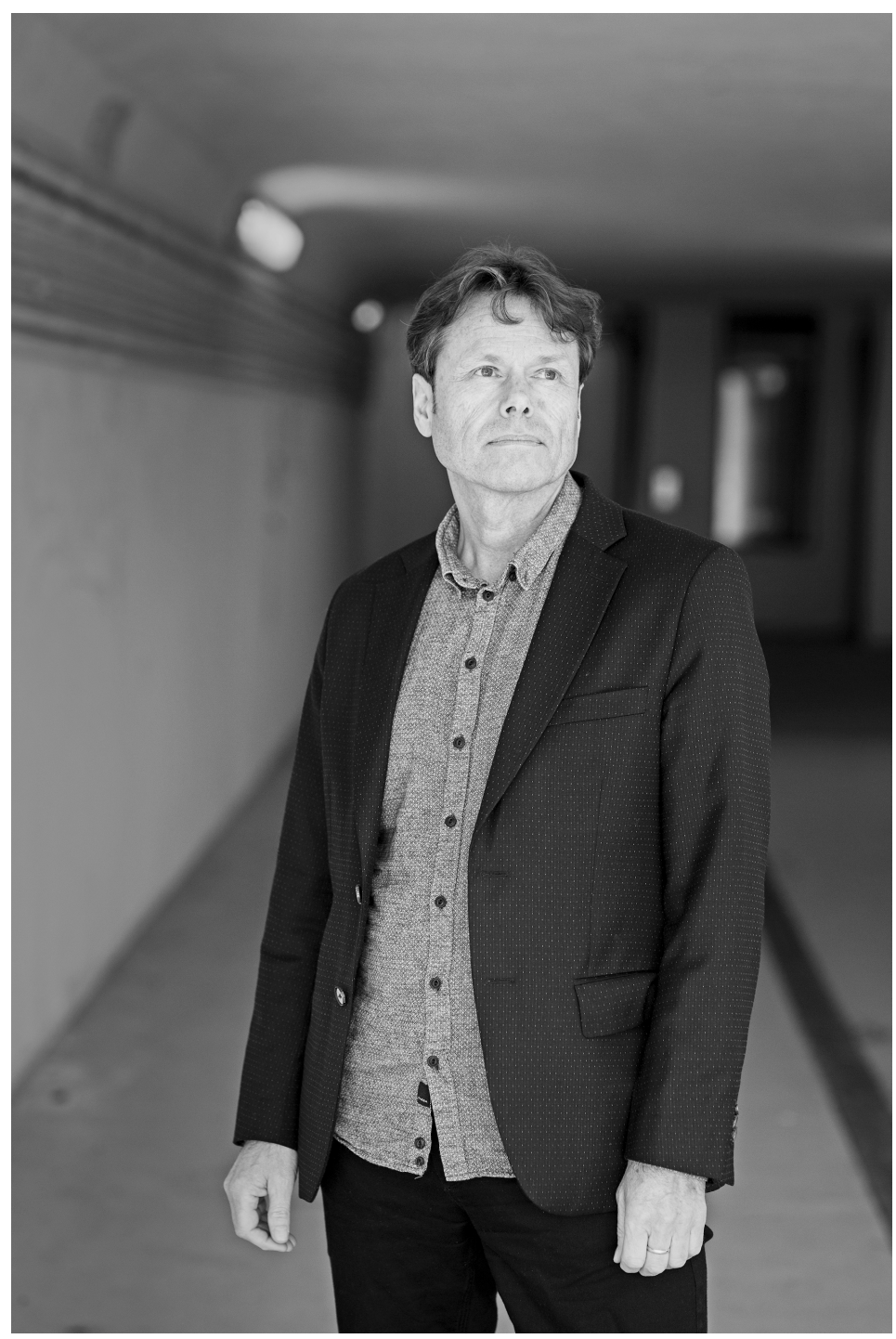

Alle foto: Kristine Lindebø

Skarp i blikket og med hvit frakk. Stetoskopet rundt halsen og en pistol i bukselinningen. 
Slik har avistegner Finn Graff valgt å portrettere Torkil Damhaug. Som hovedforfatter på Krimfestivalen 2019 måtte han finne seg i være "posterboy» på forsiden av festivalmagasinet. På innsiden kan vi lese: «Damhaug er en av de få som har vunnet Rivertonprisen for beste norske kriminalroman to ganger. Vi er derfor svært glade for å bruke både dette magasinet og festivalen til å hylle en av Norges beste krimforfattere.»

Det er som krimforfatter de fleste nordmenn kjenner han. Legelivet begynner det blir noen år siden han forlot. Verken bevæpnet eller hvitkledd møter vi han en ukes tid etter festivalslutt. Avslappet og imøtekommende lever han ikke helt opp til Graffs karikatur, og det er ikke første gang han får spørsmål om hvordan psykiatrien har påvirket ham som forfatter.

- Mine erfaringer fra psykiatrien har betydd veldig mye for meg som menneske, men jeg er alltid nøye med å understreke at jeg ikke skriver om konkrete hendelser fra klinikken. Mennesker som har vist meg den tilliten, skal ikke dukke opp i en roman. Det er det viktig for meg å få sagt, sier Damhaug.

\section{Et berøringspunkt}

I en tid der virkelighetslitteraturen debatteres og grensene for hvem og hvordan man bruker andre i romanform delvis er utvisket, er psykiateren Torkil Damhaug tydelig på dette punktet. Erfaringene fra faget har likevel vært sentrale, og han er opptatt av at det finnes fellestrekk i måten å jobbe på som forfatter og som psykiater.

- I begge disse fagfeltene må man bruke empatien på en systematisk måte. Du trener deg i å bruke ditt eget, men samtidig være mottagelig for hvem den andre er. Det å leve seg inn i den andres historie, forstå den andre fra dennes ståsted, har vært en nyttig trening for meg som romanforfatter. Jeg skriver om skjebner som er svært ulike min egen, men må samtidig finne det referansepunktet i meg selv som resonnerer med en annens liv, sier Damhaug og utdyper:

- Jeg må finne berøringspunktene i meg selv. Så kan jeg ta karakterenes historie i en helt annen retning enn det mitt liv har vært. Men det gjenkjennelsespunktet, det er jeg nødt til å finne hvis det skal bli levende karakterer av det jeg skriver.

\section{Å miste historien om seg selv}

Det er ofte leger som er hovedpersoner i romanene hans. I debutromanen Flykt, måne fra 1996 er det den kvinnelige psykiateren Anna Siboulet som er jeg-fortelleren. En ung mann blir funnet bevisstløs og ute av stand til å fortelle hvem han er. Han har mistet historien om seg selv, og Anna blir den som hjelper ham å finne tilbake til den. Både som psykiater og som forfatter har Damhaug vært opptatt av hvordan vi mennesker former og forstår historien om oss selv. 


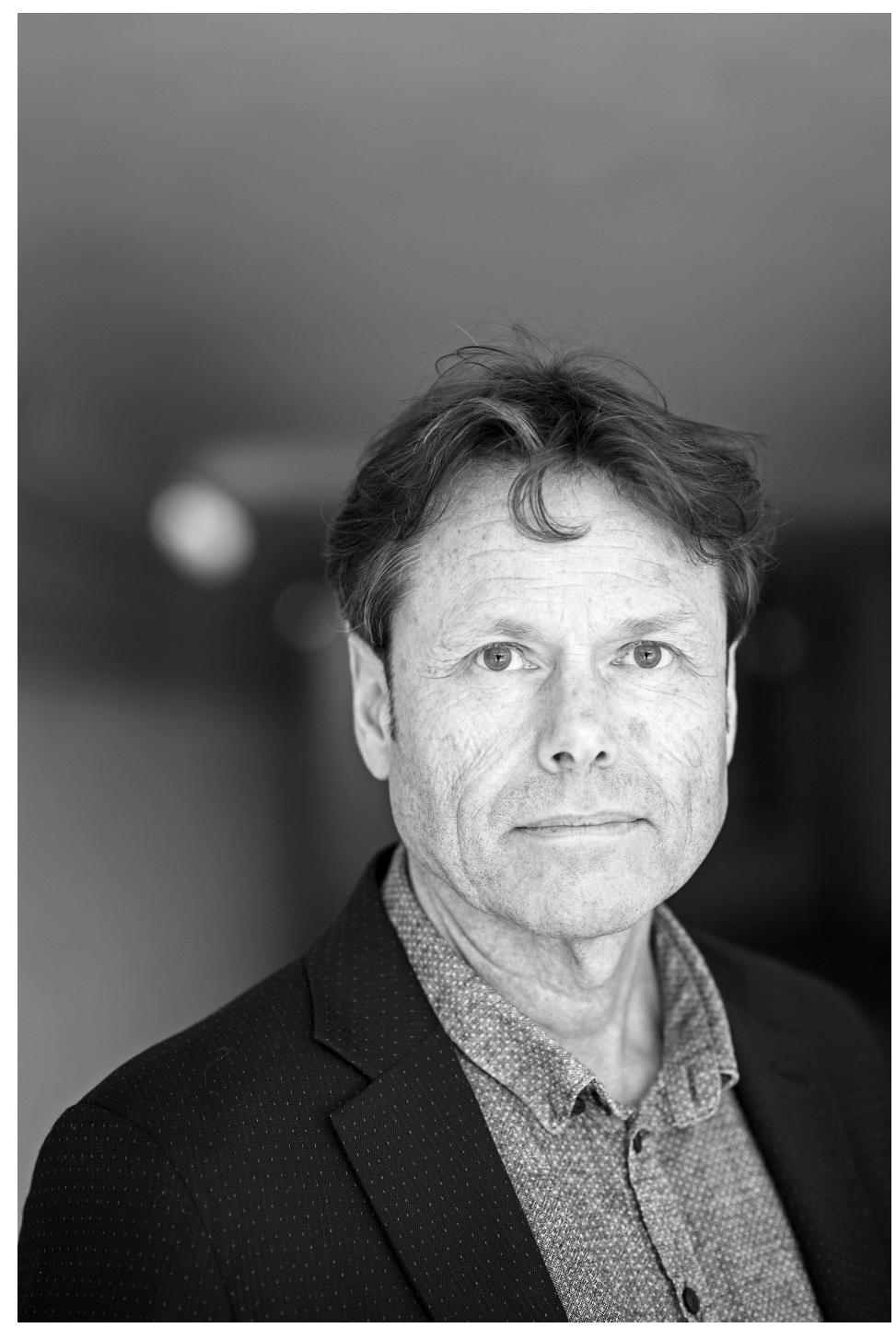

- Dette temaet går igjen i mye av det jeg skriver. Hva er hukommelse og hva er minner? Fortellingen om hvem vi er som enkeltmennesker, men også som familie, som nasjon og som sivilisasjon, har alltid interessert meg. Hvordan bruker vi disse fortellingene? Hvorfor husker vi noe fremfor noe annet? Og ikke minst, hvilke minner er det vi utelater? reflekterer han.

Jeg er alltid nøye med å understreke at jeg ikke skriver om konkrete hendelser fra klinikken

Han nevner forfatteren Edgar Allen Poe som en viktig inspirasjon i tenårene, da han begynte å skrive.

- Han beskrev også mennesker som ikke forstod seg selv. Mennesker som stod ved en avgrunn. De var redde, ikke for at noen skulle dytte, men for at de kunne komme til å hoppe. Dette fascinerte meg, sier han og legger til:

- Det er som Freud sier: Vi kan aldri forstå oss selv fullstendig. Svært mye av det ubevisste vil alltid være en utilgjengelig del av oss.

\section{Krim som tragedie}

Historier om forbrytelsen, krimfortellingen, er nettopp en sjanger som gir rom for å utforske det vi ikke forstår ved oss selv, mener Torkil Damhaug.

- Kriminalromanen holder fast på en klassisk fortellerstruktur. Hvis du leser de gamle greske tragediene, ser du at de er bygget opp som krimfortellinger. Det er et eller annet grusomt som skjer, men bakgrunnen er skjult. Så får vi gradvis økende innsikt og tror vi forstår sammenhengen, men så kommer det et vendepunkt som snur om på alt før vi til slutt får en ny og endelig innsikt. Vendepunktene innebærer en overraskelse som setter i 
gang noe emosjonelt i oss: frykt, forferdelse, men også lettelse og glede. Noe som tenner oss, sier forfatteren og fortsetter:

- Aristoteles beskrev denne fortellerformen for nærmere 2500 år siden. Grunnen til at fortellere fortsatt benytter seg av den, er kanskje at den ligger nedfelt som et slags kognitivt skjema i oss, en grunnleggende forventning til hvordan en historie skal utvikle seg. Fortellingene som virkelig griper oss, har alltid denne strukturen i seg, forklarer han.

\section{Torkil Damhaug}

Født 1958 i Lillehammer

Litteraturvitenskap mellomfag, Universitetet i Bergen 1982

Sosialantropologi grunnfag, Universitetet i Bergen 1983

Medisinsk embedseksamen, Universitetet i Oslo 1991

Turnustjeneste Lofoten sykehus/Vestvågøy kommune 1991-92

Godkjent spesialist i psykiatri 2006

Konstituert overlege og prosjekt-|teamleder for Psykoseteamet, Lillestrømklinikken

Konstituert postoverlege ved seksjon døgn, avdeling Moenga, Lillestrømklinikken

Rivertonprisen i 2007 og 2016

Når det gjelder hans egen historie, er det å vinne litterære priser, oppnå medisinsk embetseksamen og ferdig spesialitet viktige milepæler i karrieren, men det å få antatt sitt første manus var størst. Han begynte på sin første roman siste året på medisinstudiet. Hver ledige time mellom pasientarbeid, nattevakter og småbarn ble brukt til å skrive. Da han noen år senere var LIS-lege på Akershus universitetssykehus, husker han godt øyeblikket da han fikk høre at forlaget hadde tatt kontakt.

- Jeg var akkurat innom ekspedisjonen for å levere fra meg noen journaler da jeg fikk beskjed av en sekretær om at noen i Cappelen forlag hadde ringt. I det øyeblikket visste jeg at jeg kom til å debutere som forfatter. Jeg skjønte jo at de ikke ville gidde å ringe om det var for å si hvor dårlig de syntes manuset mitt var.

\section{I sine drifters vold}

På Krimfestivalen har han deltatt i en debatt om ondskapens problem, et tema han også har reist rundt og holdt foredrag om. Er det som psykiater eller forfatter dette temaet opptar ham?

- Jeg er interessert i hva som gjør at mennesker begår uhyrlige handlinger mot andre. Når jeg snakker om ondskap i denne sammenhengen er det med ulike innfallsvinkler. Ondskap er jo ikke bare det sadistiske. Det finnes mange andre former for ondskap. Noen sprenger seg selv og tar med seg uskyldige mennesker i døden, ikke fordi de er skruppelløse eller ufølsomme, men fordi de tror blindt på en ideell politisk eller religiøs målsetting, sier Damhaug.

Det å leve seg inn i den andres historie, forstå den andre fra dennes ståsted, har vært en nyttig trening for meg som romanforfatter

I den sadistiske ondskapen, den som i psykiatrien gjerne havner under fanen «antisosial personlighetsforstyrrelse», er derimot idealismen fraværende.

- Dette er en ondskap som er mer skruppelløs og som bunner i empatisvikt, hensynsløse mennesker som gjerne utnytter andre. En psykopat vil kunne begå overgrep uten å ta inn over seg hva som skjer med den andre. Men det finnes også dem som begår overgrep til tross for utviklet evne til empati. Han eller hun forstår kanskje at de påfører den andre skade, men er i en form for avhengighet eller i sine drifters vold. De kan føle skyld, men klarer ikke la være å begå nye overgrep. Dette kan kanskje kalles lidenskapens ondskap, 
summerer Damhaug.

Men han er også opptatt av hvordan systemer kan legge til rette for onde handlinger.

- Hanna Arendts betraktninger rundt Adolf Eichmann er interessante her: Har du et personlig ansvar, og er du ond når du som Eichmann egentlig bare utfører jobben din? Eichmann var en veldig pliktoppfyllende mann - en mønsterbyråkrat - innenfor et ondt system, nemlig den nazistiske staten. Men selv i et demokratisk samfunn som vårt er det slik at vi faktisk kan påføre andre mennesker lidelse og smerte uten at vi nødvendigvis mener det personlig, sier Damhaug, og viser til hvordan flyktninger som ikke får opphold i Norge kan sendes tilbake til tortur og overgrep. Som eksempel nevner han også hvordan miljøproblemer vi er med på å skape, vil kunne påføre store lidelser for kommende generasjoner, uten at vi i dag tar inn over oss disse konsekvensene.

\section{Ondskap som dysfunksjon}

I psykiatrien er likevel ikke ondskap et faglig begrep.

- Her er jo vår oppgave å hjelpe og ikke moralisere. Vi skal ikke bedømme, vi skal forstå. Samtidig står vi i fare for å sykeliggjøre, sier Damhaug. Det er umulig å ikke nevne tilfellet Breivik.

\section{Utgivelser}

Flykt, måne (Cappelen, 1996)

Syk rose (Cappelen, 1999)

Overlord (Cappelen, 2006)

Se meg, Medusa (Cappelen, 2007)

Døden ved vann (Cappelen Damm, 2009)

Ildmannen (Cappelen Damm, 2011)

Sikre tegn på din død (Cappelen Damm, 2013)

En femte årstid (Cappelen Damm, 2016)

Glasshjerte (Cappelen Damm, 2017)

Se en annen vei (Cappelen Damm, utkommer september 2019)

- Selv om rettssaken hans er et godt eksempel her, er det daglig saker i rettsapparatet i Norge der onde handlinger er begått mot andre og der spørsmålet er om man skal forklare og forsvare handlingene med at de er begått av et sykt menneske. Kan man da si at all ondskap er en form for feil i hjernen som burde vært behandlet? spør Damhaug. Han skulle gjerne fordypet seg mer i nevropsykiatrisk forskning rundt disse temaene, men med bare ett liv til rådighet konsentrerer han seg i disse dager om å levere inn sin tiende roman. Det er i litteraturen han får anledning til å utforske dette best. Ved nærmere samtale kommer det likevel frem at han savner psykiatrifaget.

Jeg er interessert i hva som gjør at mennesker begår uhyrlige handlinger mot andre

- Jeg er stadig fristet til å vende tilbake. Samtidig er det litt enten-eller, sier den tidligere overlegen. Han tar en liten pause før han fortsetter:

- Det er en god følelse å jobbe med pasienter, det å kjenne på takknemligheten ved å kunne gjøre noe for et annet menneske. Det er virkelig et meningsfullt arbeid, men så er det alt dette som har med administrasjon og organisasjon å gjøre. Det er også nødvendig, men tar mye krefter, sier Damhaug. De siste årene jobbet han som leder. Det å «krangle om budsjetter eller profesjonsgrenser, eller å måtte dokumentere til det absurde», er absolutt ikke noe han savner - selv om han understreker nødvendigheten av en effektiv organisering av arbeidet og best mulig utnyttelse av sparsomme ressurser.

- Effektivisering er veldig viktig, dette å nå et stort antall mennesker med best mulig 
tjenester. Men akkurat ordet produksjon, hva betyr det egentlig? Det blir ofte knyttet til de målbare tingene, hvor mange som kommer inn og ut av et kontor. Du kan få et veldig produktivt system, som $i k k e$ produserer helse i den forstand at det gjør folk friskere. Det er mye vanskeligere å måle kvalitet enn produktivitet, kommenterer han.

\section{De store temaene}

Igjen er vi tilbake i samtalen om de store temaene. Hva er god behandling? Hva er god medisin? Damhaug påpeker at psykiatriens mangel på gode biologiske markører stiller ekstra høye krav til klinikerens empati og sensitivitet.

- For å forstå hva du faktisk skal diagnostisere og behandle, må du gjennom innlevelsesfasen, forsøket på å forstå den andre. Noen vil kanskje mene at det kan andre faggrupper enn leger og psykiatere ta seg av ... Han fullfører ikke setningen, men det ligger under at dette ikke er Damhaugs oppfatning.

Romanskriving dreier seg mye om å finne balanse mellom distanse og nærhet

- Adferd kan beskrives og forstås utenifra, men lik atferd kan ha vidt forskjellige årsaker. Empati er uunnværlig i enhver form for psykoterapi. Skal du lykkes, må det etter min oppfatning være i alle fall et element av psykoterapi i enhver form for psykiatrisk behandling, sier psykiateren - og utdyper hvordan dette igjen tangerer det å skrive fiksjonslitteratur:

- Romanskriving dreier seg mye om å finne balanse mellom distanse og nærhet, du må finne disse innlevelsespunktene i deg selv, men samtidig ikke være så nær at du ikke ser. Du skal bruke ditt eget, men med en avstand som åpner for forståelse, avslutter forfatteren.

Publisert: 19. august 2019. Tidsskr Nor Legeforen. DOI: 10.4045/tidsskr.19.0404

(C) Tidsskrift for Den norske legeforening 2020. Lastet ned fra tidsskriftet.no 